\title{
Abnormalities of the spleen in relation to congenital malformations of the heart: a survey of necropsy findings in children
}

Department of

Pediatric Cardiology,

Children's Hospital of

Pittsburgh,

Pittsburgh,

Pennsylvania, USA

C Anderson

$\mathrm{R} H$ Anderson

J R Zuberbuhler

Department of

Pathology, Children's

Hospital of

Pittsburgh,

Pittsburgh,

Pennsylvania, USA

W A Devine

D E Debich

Correspondence to

Professor Robert $\mathrm{H}$

Anderson, Department of

Paediatrics, National Heart

and Lung Institute,

Dovehouse Street, London SW3 $6 \mathrm{LY}$.

Accepted for publication

21 September 1989

Christine Anderson, William A Devine, Robert H Anderson, Diane E Debich, James R Zuberbuhler

\section{Abstract}

A series of 1042 reports of necropsies on children dying at Children's Hospital of Pittsburgh was reviewed. In each case, note was taken of the status of the spleen, the lobation of the lungs, the arrangement of the bronchi, the morphology of the atrial appendages, and the presence of any congenital malformations of the heart and great vessels and of any malformations of the abdominal organs. There was isomerism of the left atrial appendages in eight $(0.77 \%), 13(1 \cdot 25 \%)$ showed isomerism of the right appendages, and seven $(0.67 \%)$ had multiple spleens without having isomerism of the atrial appendages. Unexpectedly, a normal spleen was found in one patient with isomerism of the right appendages and also in a patient with isomerism of the left appendages. In one patient with isomeric left atrial appendages there was no spleen. The review showed that the morphology of the atrial appendages, and hence the arrangement of the atria, is not accurately predicted by the type of spleen. The arrangement of the atrial appendages is the most reliable guide to the recognised combinations of congenital cardiac malformations previously

described as "splenic syndromes" Because there is no certain way of predicting all the malformations in patients with complex congenital heart disease, it is advisable to record separately for each patient the details of lobation of the lungs, the bronchial and atrial arrangement, anomalies of the heart and great vessels, the type of spleen, and any abnormal arrangement of the abdominal organs.

It is now well recognised that complex congenital malformations of the heart are associated with abnormalities of the spleen and abnormal arrangement of the other thoracoabdominal organs..$^{1-3}$ Although it became fashionable to call these cardiac syndromes "asplenia" and "polysplenia"," it has since become clear that these are imperfect terms to describe the heart and its contained anomalies. This is because some patients without spleens have the constellation of lesions expected in "polysplenia", whereas the malformations expected in "asplenia" can be found in patients with single or multiple spleens. ${ }^{56}$ The presence of right or left isomerism of the atrial appendages $^{6-8}$ is a much more accurate guide to the characteristic syndromes. Furthermore, some patients with multiple spleens and left isomer-
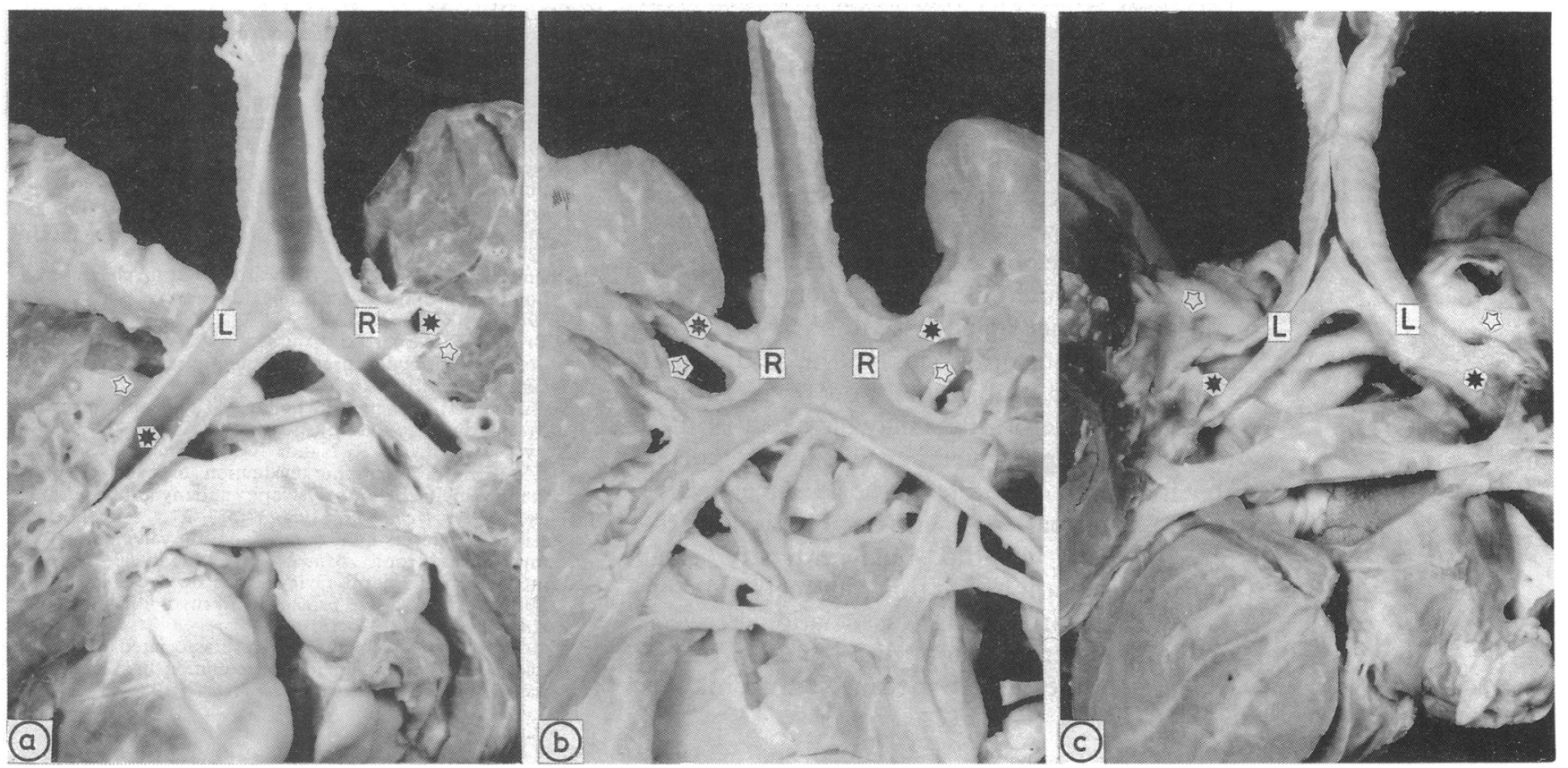

Figure 1 The arrangements of the bronchi are shown from behind in (a) a normal heart, (b) a heart with isomerism of the right bronchi, and (c) a heart with left bronchial isomerism. The left bronchus $(L)$ is longer than the right $(R)$. The morphologically left bronchus is below the pulmonary artery (hyparterial) while the morphologically right bronchus is above the artery (eparterial). Black star = bronchus; white star = pulmonary artery. 


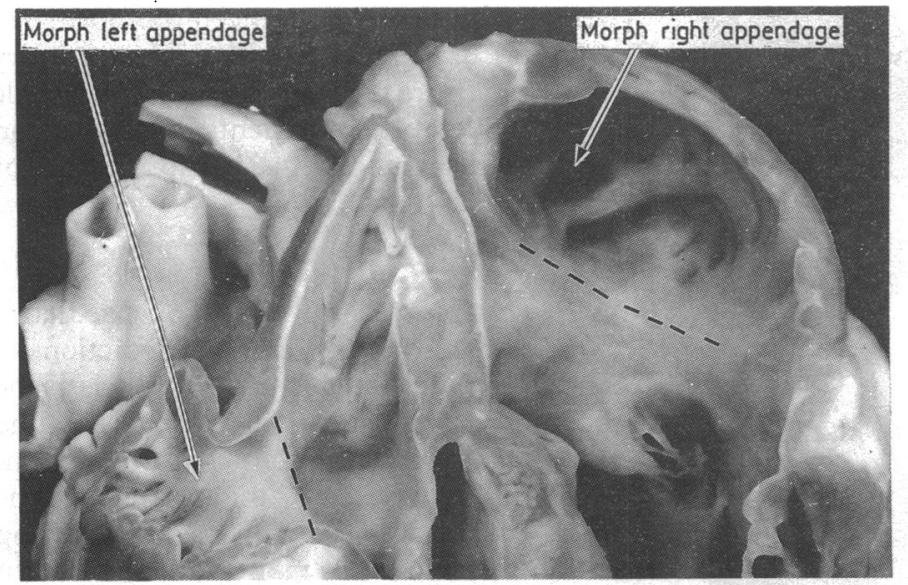

Figure 2 The normal heart is opened out to show the internal structures of the morphologically left and right atria. The tubular left atrial appendage has a narrow junction with the venous component of the atrium whereas the triangular right atrial appendage has a broad junction (dotted lines).

ism of the thoracic organs can have normally constructed hearts with the atria in their normal position. ${ }^{19}$ But how common is this finding? And how frequently are accessory, as opposed to multiple, spleens encountered by the paediatric pathologist? These questions are vital for those who try to understand and categorise congenital malformations of the heart. $^{1011}$ To answer them, we have reviewed the necropsy records from Children's Hospital of Pittsburgh over an 11 year period to ascertain the frequency and relation of abnormalities of the heart and thoracoabdominal organs.

\section{Patients and methods}

We examined the detailed reports on the 1158 necropsies carried out on children who died at the Children's Hospital of Pittsburgh from 1976 to 1986 inclusive. Of these reports, 116 were not included in the final analyses because

Figure 3 Multiple spleens. the necropsy had either been exclusively thoracic or abdominal. We did not include two cases of conjoined twins because their hearts were fused.

We took information on the arrangement of the lungs, bronchi (fig 1), and atrial appendages (fig 2) from each report and noted any congenital abnormalities of the heart and great vessels. These structures were assumed to be normal if not specifically described to the contrary. The state of the spleen was recorded, as well as any evidence of abnormal arrangement of the other abdominal organs. The spleen was designated to be normal, absent, multiple (fig 3), or accompanied by accessory splenules (fig 4). Multiple spleens were recorded only when specifically described as such by the reporting pathologist. It was more common for additional splenic tissue, when noted, to be reported as accessory. The hearts of all the patients with isomerism of the atrial appendages had been retained in the Heart Museum. We re-examined these in sequential segmental fashion, making particular note of the venoatrial connections and any associated malformations (fig 5).

\section{Results}

Table 1 shows the general findings from the survey of the 1042 cases, broken down according to splenic morphology. According to the morphology of the atrial appendages, a total of eight patients $(0.77 \%)$ in the overall series showed morphologically left isomerism (table 2) while $13(1.25 \%)$ showed morphologically right isomerism (table 3). Another seven cases $(0.67 \%)$ were discovered to have multiple spleens without any evidence of isomerism of the atrial appendages (table 4). There were no instances of complete absence of the spleen without left or right isomerism of the atrial appendages, but four cases had hypoplastic spleens (weighing, on average, $1.6 \mathrm{~g}$ ). The spleen in one weighed only $0.6 \mathrm{~g}$.

Five of the 116 incomplete reports are worthy of mention. Two were described as having "polysplenia", but a postmortem examination of the thoracic organs had not been performed to confirm the presence (or absence) of isomerism of the appendages. Another patient showed isomerism of the left atrial appendages and one isomerism of the right appendages, but no abdominal inspection had been carried out to record the state of the spleen. A fifth example of isomerism of the right appendages was noted in one of the conjoined twins. It is probable, therefore, that these cases would have increased the incidence of isomerism of the left and right appendages in the overall population.

Two of the 1042 cases had a mirror image atrial arrangement. Because the position of the lungs, bronchi, and abdominal organs showed appropriate mirror imagery these were all included in the category of those having normal spleens and lungs with attendant congenital heart disease.

There were 11 reports $(1.06 \%)$ of accessory spleens accompanied by malrotation of the gut. 


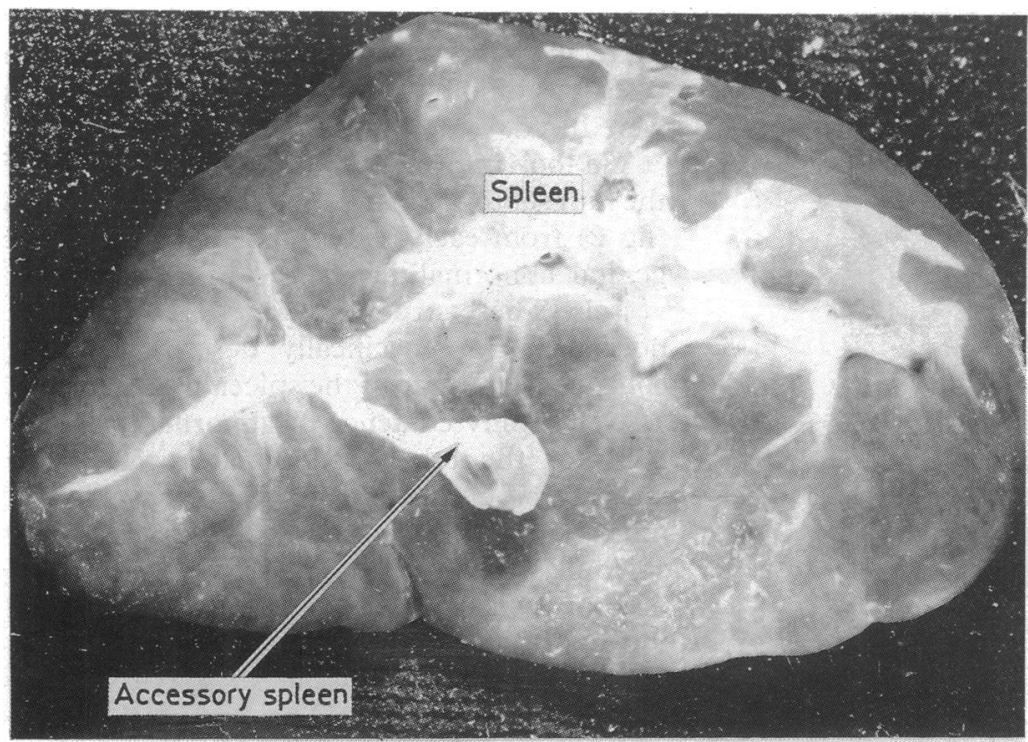

Figure 4 An accessory spleen.

One of these also had bilaterally bilobed lungs and hyparterial bronchi but all showed the usual atrial arrangement. Ten had diaphragmatic hernias, chromosomal disorders, or biliary atresia. Four cases had congenital heart disease, but not in the combinations expected for isomerism of the atrial appendages.

Isolated malrotation of the gut with a normal spleen was noted in 19 necropsies $(1.82 \%)$. In 13 of these there were either diaphragmatic hernias or chromosomal disorders. Atrial arrangement was usual in all instances, with nine patients having some form of congenital heart disease. Abnormal lung lobation was mentioned twice, but neither patient had an isomeric arrangement of the bronchi.

Abnormalities of lobation of the lungs were reported in 80 cases $(7.68 \%)$. Thirteen $(1.25 \%)$ of these had bilaterally trilobed lungs (one case also having bilaterally eparterial bronchi). The spleen was normal in nine of these patients and the other four had accessory spleens. None had either form of isomerism of the atrial appendages or their cardiac manifestations. Forty four $(4 \cdot 22 \%)$ reports noted bilaterally bilobed lungs (four with accompanying bilaterally

Table 1 Summary of findings from 1042 necropsies

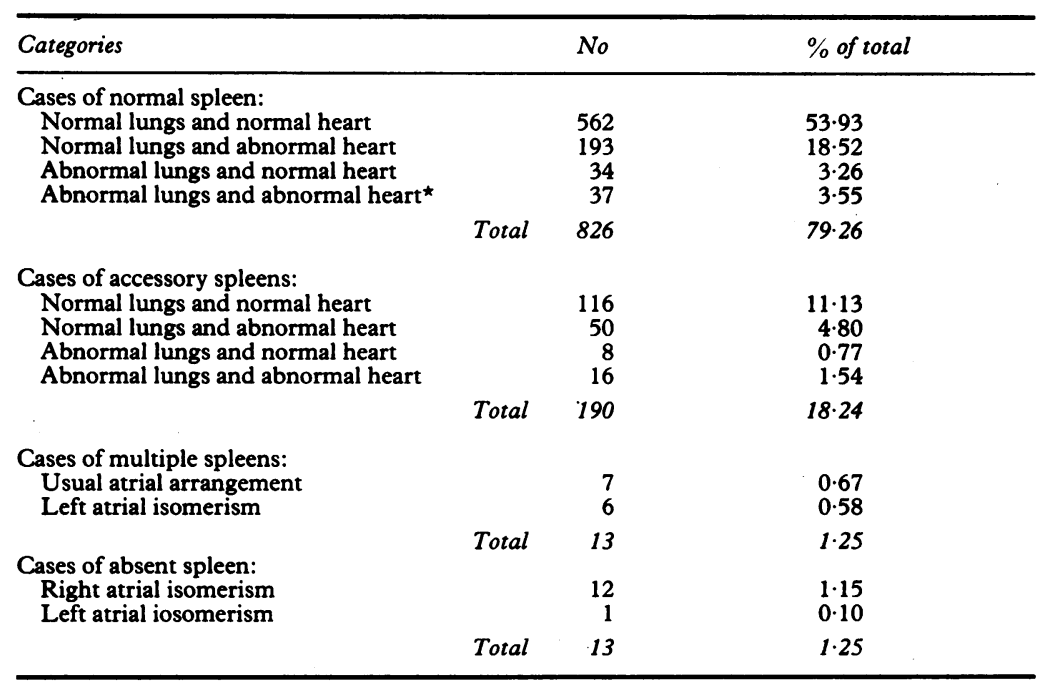

‡One case had right atrial isomerism. hyparterial bronchi). The spleen was normal in 35 of these patients, eight had accessory spleens, and the remaining patient had multiple spleens. None of these patients, however, had either isomerism of the left atrial appendages or the expected cardiac lesions.

\section{Discussion}

Our review of a large series of paediatric necropsies confirms our earlier predictions. ${ }^{35}$ It is no longer reasonable to attempt to describe or diagnose congenital malformations of the heart in terms of abnormalities of the spleen. The attention given to the "splenic syndromes" has served its purpose in drawing attention to the cardiac malformations known to accompany them.

Our findings emphasise the relative constancy of the cardiac lesions themselves. Thus on the one hand there are hearts characterised by bilateral atrial appendages of right morphology. These hearts have bilateral superior caval veins, totally anomalous pulmonary venous connection, a common atrioventricular valve, and a high proportion of double inlet atrioventricular connection and an abnormal ventriculoarterial connection, usually with pulmonary stenosis or atresia. ${ }^{1}$ On the other hand there are hearts with bilateral appendages of left morphology. These hearts characteristically have bilateral superior venae cavae (caval veins) and a common atrioventricular valve, but they have a relatively normal arrangement of their ventricular mass, coarctation rather than pulmonary atresia, and an anomalous connection of the inferior vena cava (caval vein), usually with azygos continuation. ${ }^{28}$ The most accurate guide to the presence of these cardiac lesions is neither absence of the spleen nor the presence of multiple spleens. It is the existence of isomerism of the atrial appendages. ${ }^{6}$

When we describe "atrial isomerism", it should not be presumed that each atrium, along with its venous connections, is an isomer of the other. Far from it. The isomerism affects only the appendages, and these structures are truly isomeric. In this respect, it is the appendages that fulfil the criteria established by Van Praagh and his colleagues for determining the morphology of any cardiac chamber. ${ }^{12}$ The principle they established ${ }^{12}$ is called the morphologic method. In essence, it states that chambers within the heart should be identified according to their most constant components. It had been suggested that the inferior vena cava (caval vein) was the most constant atrial component, serving in this way to identify the morphologically right atrium. ${ }^{13}$ The analysis of the present patients shows that this is not the case.

In our patients with abnormal arrangement of the abdominal organs, where it is most necessary accurately to determine atrial morphology, presence or absence of the inferior vena cava (caval vein) provides an ineffective marker of the morphologically right atrium. In contrast, all patients with the constellation of cardiac lesions previously known as "splenic syndromes" would have been correctly iden- 
Figure 5 The top panels show a heart with isomerism of the right atrial appendages: (a) right sided atrium, (b) left sided atrium. Note the presence of bilateral venae cavae and terminal crests. The lower panels show the internal arrangement of the atria in the presence of isomerism of the left atrial appendages: (c) right sided atrium, (d) left sided atrium. Note the presence of bilateral superior venae cavae and pulmonary veins connecting directly to the atria. $M R A A$, morphologically right atrial appendage; $R A A$, right atrial appendage; morph, morphologically; $M L A A$, morphological left atrial appendage, pulm, pulmonary.
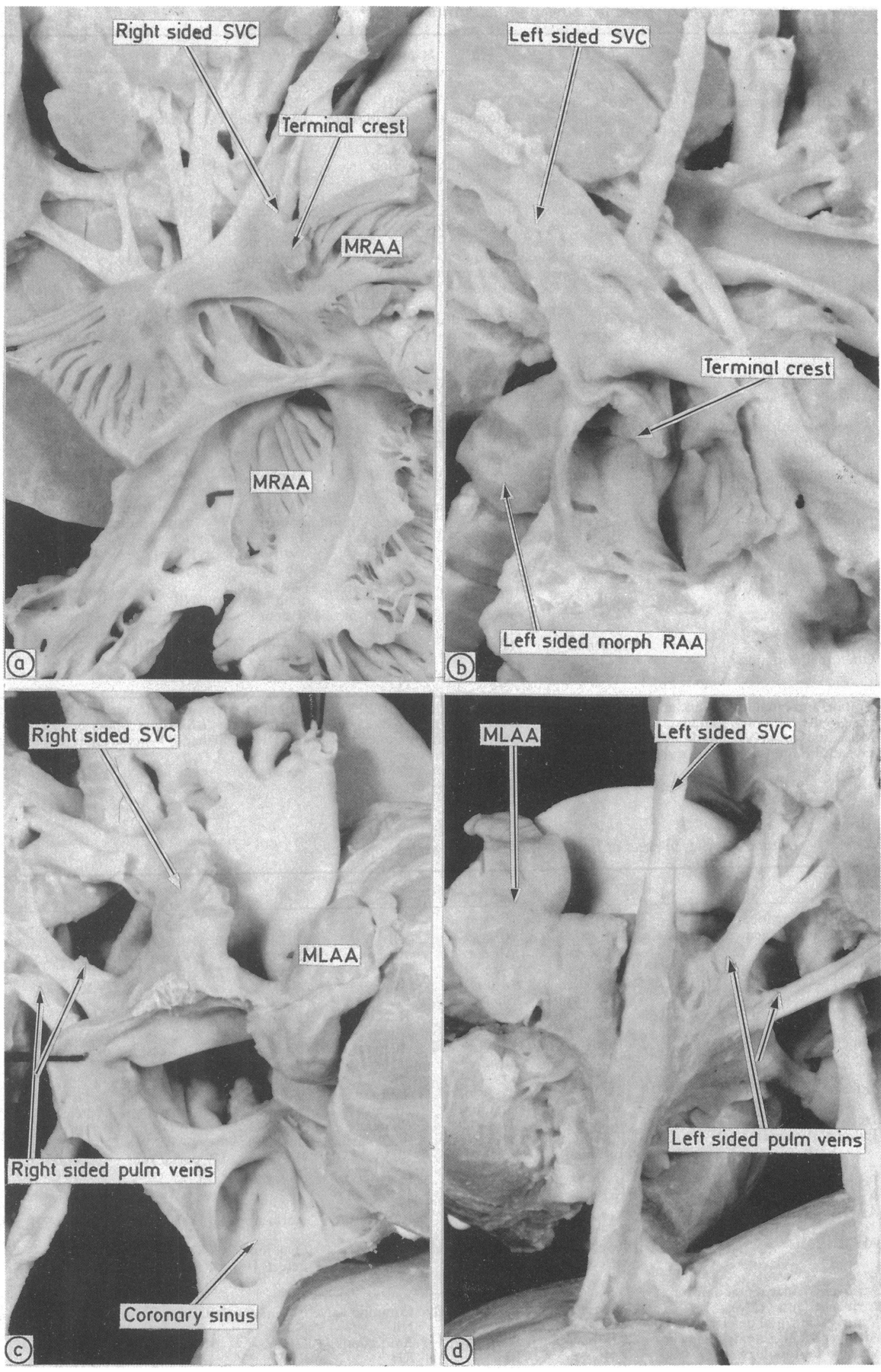

tified on the basis of isomerism of their atrial appendages. Thus the anatomy of the appendage and the arrangement of its junction with the venous atrial component provide an accurate means of distinguishing the morphologically right and left atria even in the presence of the most complex malformations of the heart. It is this criterion that best determines the arrangement of the atria. Furthermore, when the atria are abnormally formed in association with congenital cardiac anomalies, it is more accurate to describe them in terms of atrial isomerism rather than invoking considerations of malformations of the spleen.

Determining the arrangement of the atria is relatively easy for the pathologist, who holds the heart in his hands, and also for the cardiac surgeon, who can readily recognise the structure of the appendages as seen in the operating room. But what of the clinician, who is often 
Table 2 Details of eight cases of isomerism of the left atrial appendages

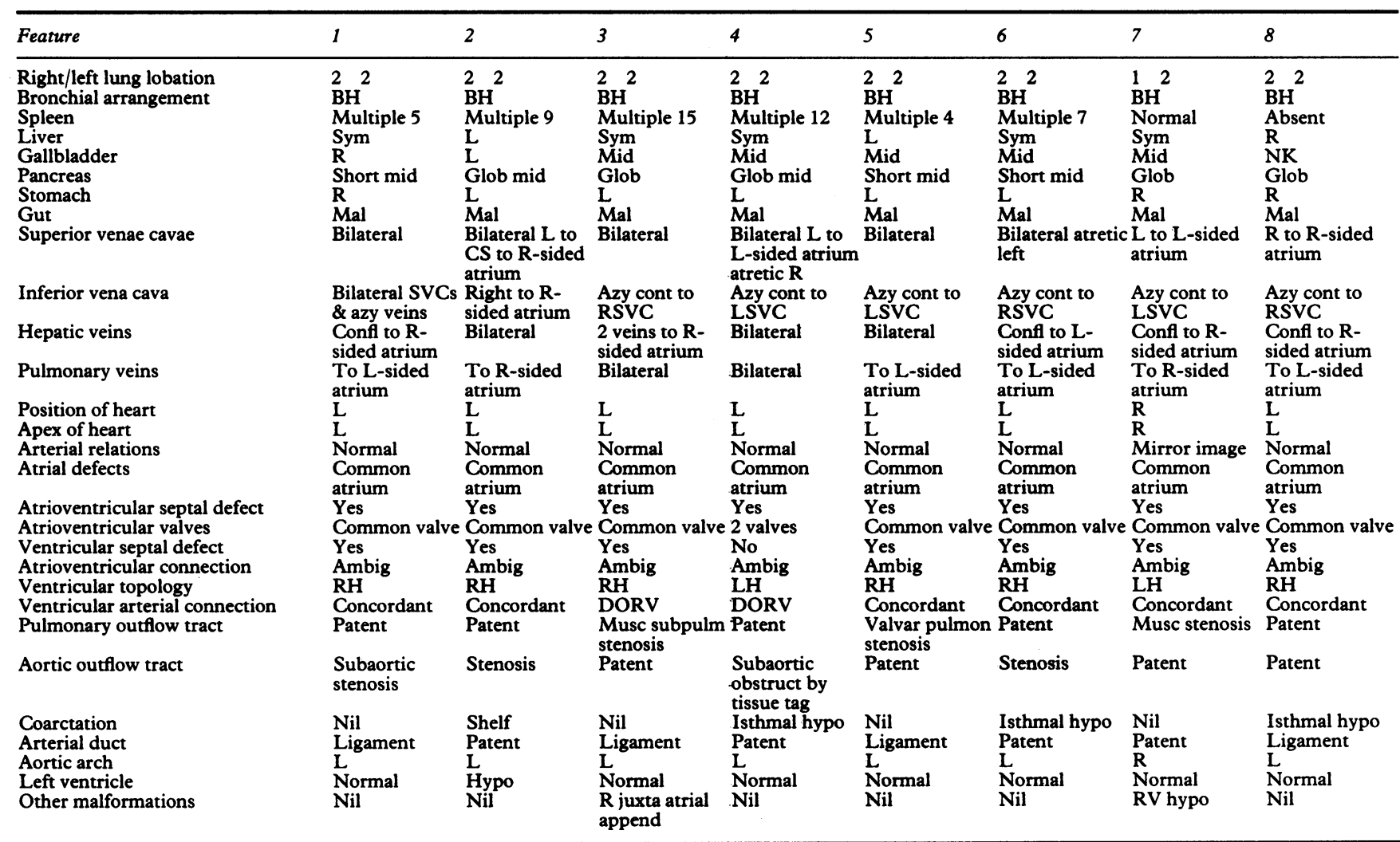

Ambig, ambiguous; append, appendages; azy cont, azygos continuation; BH, bilaterally hyparterial; Conf, confluent; CS, coronary sinus; DORV, double outle right ventricle; Glob, globular; Hypo, hypoplasia; L, left; LH, left-hand; Ligament, ligamentous; LSVC, left superior vena cava; Mal, malrotation; Mid, midline; Musc, muscular; NK, not known; Obstruct, obstruction; Pulmon, pulmonary; R, right; RH, right-hand; $R$ juxta, right juxtaposition of; RSVC, right superior vena cava; Subpulm, subpulmonary; Sym, symmetrical.

Table 3 Details of thirteen cases of isomerism of the right atrial appendages

\begin{tabular}{|c|c|c|c|c|c|c|c|c|}
\hline Feature & 1 & 2 & 3 & 4 & 5 & 6 & 7 & 8 \\
\hline $\begin{array}{l}\text { Right/left lung lobation } \\
\text { Bronchial arrangement } \\
\text { Spleen } \\
\text { Liver } \\
\text { Gallbladder } \\
\text { Pancreas } \\
\text { Stomach } \\
\text { Gut } \\
\text { Superior venae cavae }\end{array}$ & $\begin{array}{l}3 \quad 3 \\
\text { BE } \\
\text { Absent } \\
\text { Sym } \\
\mathbf{R} \\
\text { Short mid } \\
\text { Mid } \\
\text { Mal } \\
\text { Bilateral atretic } \\
\text { right }\end{array}$ & $\begin{array}{l}3{ }^{3} \\
\text { BE } \\
\text { Absent } \\
\text { Sym } \\
\text { Mid } \\
\text { Short mid } \\
\text { R } \\
\text { Mal } \\
\text { L to L-sided } \\
\text { atrium }\end{array}$ & $\begin{array}{l}3 \quad 3 \\
\text { BE } \\
\text { Absent } \\
\text { L } \\
\text { Mid } \\
\text { Glob mid } \\
\text { R } \\
\text { Mal } \\
\text { Bilateral }\end{array}$ & $\begin{array}{l}3{ }^{3} 3 \\
\text { BE } \\
\text { Normal } \\
\text { Sym } \\
\text { NK } \\
\text { L } \\
\text { L } \\
\text { Normal } \\
\text { Bilateral; L to } \\
\text { L-sided A; } \\
\text { atretic R }\end{array}$ & $\begin{array}{l}3 \quad 3 \\
\text { BE } \\
\text { Absent } \\
\text { Sym } \\
\text { NK } \\
\text { NK } \\
\text { NK } \\
\text { Mal } \\
\text { Bilateral }\end{array}$ & $\begin{array}{l}\text { B }^{3} \\
\text { BE } \\
\text { Absent } \\
\mathbf{R} \\
\mathbf{R} \\
\mathbf{R} \\
\mathbf{R} \\
\text { Mal } \\
\text { Bilateral }\end{array}$ & $\begin{array}{l}2 \quad 2 \\
\text { BE } \\
\text { Absent } \\
\text { Sym } \\
\text { L } \\
\mathbf{R} \\
\mathbf{R} \\
\text { Mal } \\
\text { Bilateral atretic } \\
\text { left }\end{array}$ & $\begin{array}{l}3 \quad 2 \\
\text { BE } \\
\text { Absent } \\
\text { Sym } \\
\text { R } \\
\text { Elong } \\
\text { NK } \\
\text { Mal } \\
\text { Bilateral }\end{array}$ \\
\hline $\begin{array}{l}\text { Inferior vena cava } \\
\text { Hepatic veins } \\
\text { Pulmonary veins }\end{array}$ & $\begin{array}{l}\text { To L-sided } \\
\text { atrium } \\
\text { Bilateral } \\
\text { TAPVC } \\
\text { Infradia }\end{array}$ & $\begin{array}{l}\text { To } R \text {-sided } \\
\text { atrium } \\
\text { To IVC } \\
\text { TAPVC to } \\
\text { portal vein }\end{array}$ & $\begin{array}{l}\text { To L-sided } \\
\text { atrium } \\
\text { Bilateral } \\
\text { TAPVC to } \\
\text { RSVC }\end{array}$ & $\begin{array}{l}\text { To L-sided } \\
\text { atrium } \\
\text { To IVC } \\
\text { TAPVC to } \\
\text { RSVC }\end{array}$ & $\begin{array}{l}\text { To L-sided } \\
\text { atrium } \\
\text { To IVC } \\
\text { TAPVC to } \\
\text { portal vein }\end{array}$ & $\begin{array}{l}\text { To R-sided } \\
\text { atrium } \\
\text { To IVC } \\
\text { TAPVC R to } \\
\text { portal L to } \\
\text { LSVC }\end{array}$ & $\begin{array}{l}\text { To R-sided } \\
\text { atrium } \\
\text { To IVC } \\
\text { TAPVC to R- } \\
\text { sided A }\end{array}$ & $\begin{array}{l}\text { To L-sided } \\
\text { atrium } \\
\text { To IVC } \\
\text { TAPVC to R- } \\
\text { sided A }\end{array}$ \\
\hline $\begin{array}{l}\text { Position of heart } \\
\text { Apex of heart } \\
\text { Arterial relations }\end{array}$ & $\begin{array}{l}\mathrm{R} \\
\mathrm{R} \\
\text { Aorta ant }\end{array}$ & $\begin{array}{l}\mathbf{R} \\
\mathbf{R} \\
\text { Aorta to } \mathbf{R}\end{array}$ & $\begin{array}{l}\text { L } \\
\text { L } \\
\text { Aorta ant \& } \\
\text { right }\end{array}$ & $\begin{array}{l}\text { L } \\
\text { L } \\
\text { Aorta ant }\end{array}$ & $\begin{array}{l}\text { L } \\
\text { L } \\
\text { Aorta ant }\end{array}$ & $\begin{array}{l}\mathrm{L} \\
\mathrm{L} \\
\text { Aorta to } \mathrm{R} \text { side } \\
\text { by side }\end{array}$ & $\begin{array}{l}\mathrm{R} \\
\mathrm{R} \\
\text { Aorta ant }\end{array}$ & $\begin{array}{l}\mathrm{R} \\
\mathrm{R} \\
\text { Aorta ant }\end{array}$ \\
\hline $\begin{array}{l}\text { Atrioventricular septal defect } \\
\text { Atrioventricular valves } \\
\text { Ventricular septal defect } \\
\text { Atrioventricular connection } \\
\text { Ventricular topology } \\
\text { Ventricular arterial connection } \\
\text { Pulmonary outflow tract }\end{array}$ & $\begin{array}{l}\text { Yes } \\
\text { Common valve } \\
\text { Yes (AVSD) } \\
\text { Ambiguous } \\
\text { LH } \\
\text { Discordant } \\
\text { PA }\end{array}$ & $\begin{array}{l}\text { Nil } \\
\text { Common valve } \\
\text { Yes } \\
\text { DIRV } \\
\text { RH } \\
\text { DORV } \\
\text { Subpulm } \\
\text { stenosis }\end{array}$ & $\begin{array}{l}\text { Yes } \\
\text { Common valve } \\
\text { Nil } \\
\text { Ambiguous } \\
\text { RH } \\
\text { DORV }\end{array}$ & $\begin{array}{l}\text { Nil } \\
\text { Common valve } \\
\text { Nil } \\
\text { DIRV } \\
\text { RH } \\
\text { Single outlet } \\
\text { Ao from RV } \\
\text { PA }\end{array}$ & $\begin{array}{l}\text { Yes } \\
\text { Yommon valve } \\
\text { Ambiguous } \\
\text { RH } \\
\text { Single outlet } \\
\text { Ao from RV } \\
\text { PA }\end{array}$ & $\begin{array}{l}\text { Nil } \\
\text { Common valv } \\
\text { Nil } \\
\text { DILV } \\
\text { LH } \\
\text { Concordant } \\
\text { PA }\end{array}$ & $\begin{array}{l}\text { Nil } \\
\text { Common valve } \\
\text { Yes } \\
\text { DILV } \\
\text { LH } \\
\text { Single outlet } \\
\text { Ao from RV } \\
\text { PA }\end{array}$ & $\begin{array}{l}\text { Nil } \\
\text { Common valve } \\
\text { Nil } \\
\text { DIIV } \\
\text { NA } \\
\text { Single outlet } \\
\text { Ao from IV } \\
\text { PA }\end{array}$ \\
\hline $\begin{array}{l}\text { Aortic outflow tract } \\
\text { Coarctation } \\
\text { Ductus arteriosus }\end{array}$ & $\begin{array}{l}\text { Patent } \\
\text { Nil } \\
\text { Patent to confl } \\
\text { PAs }\end{array}$ & $\begin{array}{l}\text { Patent } \\
\text { Nil } \\
\text { Patent }\end{array}$ & $\begin{array}{l}\text { Patent } \\
\text { Nil } \\
\text { Ligament }\end{array}$ & $\begin{array}{l}\text { Patent } \\
\text { Nil } \\
\text { R-sided patent }\end{array}$ & $\begin{array}{l}\text { Patent } \\
\text { Nil } \\
\text { R-sided patent }\end{array}$ & $\begin{array}{l}\text { Patent } \\
\text { Nil } \\
\text { R-sided patent }\end{array}$ & $\begin{array}{l}\text { Patent } \\
\text { Nil } \\
\text { R-sided patent }\end{array}$ & $\begin{array}{l}\text { Patent } \\
\text { Nil } \\
\text { Ligament }\end{array}$ \\
\hline $\begin{array}{l}\text { Aortic arch } \\
\text { Left ventricle } \\
\text { Other malformations }\end{array}$ & $\begin{array}{l}\text { R } \\
\text { Hypo } \\
\text { Nil }\end{array}$ & $\begin{array}{l}\text { R } \\
\text { Slit-like } \\
\text { Nil }\end{array}$ & $\begin{array}{l}\text { R } \\
\text { Hypo } \\
\text { Imperf LAVV }\end{array}$ & $\begin{array}{l}\text { L } \\
\text { Slit-like } \\
\text { Nil }\end{array}$ & $\begin{array}{l}\text { L } \\
\text { Normal } \\
\text { Nil }\end{array}$ & $\begin{array}{l}\text { L } \\
\text { Dominant } \\
\text { RV grossly } \\
\text { hypo }\end{array}$ & $\begin{array}{l}\text { R } \\
\text { Normal } \\
\text { Rudimentary } \\
\text { RV }\end{array}$ & $\begin{array}{l}\text { R } \\
\text { Solitary IV }\end{array}$ \\
\hline
\end{tabular}

Ant, anterior; Ao, aorta; AVSD, atrial or ventricular component of atrioventricular septal defect; BE, bilaterally hyparterial; DIIV, double inlet indeterminate ventricle; DILV, double inlet left ventricle; DIRV, double inlet right ventricle; Elong, elongated; IVC, inferior vena cava; Imperf LAVV, imperforate left atrioventricular valve; Infradia, infradiaphragmatic; IV, solitary and indeterminate ventricle; L-sided A, left-sided atrium; NA, not applicable; PA, pulmonary atresia; PAs, pulmonary arteries; $R$-sided $A$, right-sided atrium; $R V$, right ventricle; TAPVC, totally anomalous pulmonary venous connection. 
Table 4 Details of seven cases of multiple spleens and usual atrial arrangement

\begin{tabular}{|c|c|c|c|c|c|c|c|c|}
\hline $\begin{array}{l}\text { Case } \\
\text { No }\end{array}$ & $\begin{array}{l}\text { Right lung } \\
\text { lobation }\end{array}$ & $\begin{array}{l}\text { Left lung } \\
\text { lobation }\end{array}$ & $\begin{array}{l}\text { Bronchial } \\
\text { arrangement }\end{array}$ & $\begin{array}{l}\text { No of } \\
\text { spleens }\end{array}$ & $\begin{array}{l}\text { Abnormal } \\
\text { abdominal organs }\end{array}$ & Heart defects & $\begin{array}{l}\text { Azygos } \\
\text { continuation of } \\
\text { inferior vena cava }\end{array}$ & $\begin{array}{l}\text { Other } \\
\text { malformations }\end{array}$ \\
\hline 1 & 3 & 2 & Usual & 6 & \multirow{3}{*}{$\begin{array}{l}\text { Globular pancreas, absent } \\
\text { gallbladder } \\
\text { Globular midline pancreas, } \\
\text { malrotated gut } \\
\text { Malrotated gut }\end{array}$} & Nil & No & Biliary atresia \\
\hline 2 & 3 & 2 & Usual & 7 & & \multirow{2}{*}{$\begin{array}{l}\text { ASD, Ao-pulmonary } \\
\text { window } \\
\text { Nil }\end{array}$} & No & Biliary atresia \\
\hline 3 & 3 & 2 & Usual & 6 & & & No & $\begin{array}{l}\text { Pneumococcal } \\
\text { septicaemia }\end{array}$ \\
\hline 4 & $3+A c c$ & $2+$ Acc & Usual & 4 & \multirow{4}{*}{$\begin{array}{l}\text { Malformed stomach and } \\
\text { pancreas } \\
\text { Absent gallbladder, short } \\
\text { pancreas, malrotated gut } \\
\text { Globular midline pancreas, } \\
\text { partially malrotated gut } \\
\text { Malformed pancreas, } \\
\text { malrotated gut }\end{array}$} & $\begin{array}{l}\text { POF, ductus arteriosus, } \\
\text { LSVC to CS }\end{array}$ & Yes & Diaphragmatic hernia \\
\hline 5 & 2 & 2 & Usual & 17 & & Nil & No & Biliary atresia \\
\hline 6 & 2 & 2 & Bilat hypart & 5 & & Nil & Yes & Biliary atresia \\
\hline 7 & 2 & 1 & Usual & 9 & & POF & No & $\begin{array}{l}\text { Arnold-Chiari } \\
\text { malformation }\end{array}$ \\
\hline
\end{tabular}

Acc, accessory lobe; ASD, atrial septal defect; Ao-pulmonary, Aorto-pulmonary; Bilat hypart, bilaterally hyparterial; LSVC to CS, left superior vena cava to coronary sinus; POF, patent oval foramen.

unable accurately to distinguish the morphology of the appendages and the nature of their junctions with the venous components. It is recognised that inferences must be made in these circumstances to permit the paediatric cardiologist to assess atrial arrangement, although it has been suggested that cross sectional echocardiography may, in skilled hands, permit direct recognition of the appendages. Similarly, if injections of contrast material are made into the atrial appendages, cineangiography permits direct diagnosis of atrial isomerism. None the less, if inferences are to be made, our analysis shows that bronchial morphology ${ }^{14}$ is the best guide to the existence of isomerism of the atrial appendages. All but one case with atrial isomerism also had bronchial isomerism. The exception was a case of right atrial isomerism with usual bronchial

\begin{tabular}{|c|c|c|c|c|}
\hline 9 & 10 & 11 & 12 & 13 \\
\hline $\begin{array}{l}3{ }^{3} 3 \\
\text { BE } \\
\text { Absent } \\
\text { Sym } \\
\text { L } \\
\text { NK } \\
\text { L } \\
\text { Mal } \\
\text { Bilateral }\end{array}$ & $\begin{array}{l}2 \quad 3 \\
\text { Mirror image } \\
\text { Absent } \\
\text { Sym } \\
\mathrm{L} \\
\mathrm{R} \\
\mathrm{R} \\
\text { Mal } \\
\text { Right to R-sided } \\
\text { atrium }\end{array}$ & $\begin{array}{l}3{ }^{2} 2 \\
\text { BE } \\
\text { Absent } \\
\mathrm{L} \\
\mathrm{L} \\
\mathrm{R} \\
\mathrm{R} \\
\text { Mal } \\
\text { Bilateral }\end{array}$ & $\begin{array}{l}1 \quad 1 \\
\text { BE } \\
\text { Absent } \\
\text { Sym } \\
\text { NK } \\
\text { NK } \\
\text { NK } \\
\text { Normal } \\
\text { Bilateral }\end{array}$ & $\begin{array}{l}32^{2} \\
\text { BE } \\
\text { Absent } \\
\text { Sym } \\
\text { L } \\
\text { R } \\
\text { L } \\
\text { Mal } \\
\text { Left to L-sided } \\
\text { atrium }\end{array}$ \\
\hline $\begin{array}{l}\text { To L-sided } \\
\text { atrium } \\
\text { Bilateral } \\
\text { TAPVC to portal } \\
\text { vein }\end{array}$ & $\begin{array}{l}\mathrm{L} \text { to } \mathrm{L} \text {-sided } \\
\text { atrium } \\
\text { To IVC } \\
\text { TAPVC to portal } \\
\text { vein }\end{array}$ & $\begin{array}{l}\text { To L-sided } \\
\text { atrium } \\
\text { Bilateral } \\
\text { TAPVC to } \\
\text { R-sided A }\end{array}$ & $\begin{array}{l}\text { To R-sided } \\
\text { atrium } \\
\text { To IVC } \\
\text { TAPVC to } \\
\text { R-sided A }\end{array}$ & $\begin{array}{l}\text { To L-sided } \\
\text { atrium } \\
\text { To IVC } \\
\text { TAPVC to R- } \\
\text { sided A }\end{array}$ \\
\hline $\begin{array}{l}\mathbf{R} \\
\mathbf{R} \\
\text { Aorta ant \& left }\end{array}$ & $\begin{array}{l}\mathrm{R} \\
\mathrm{R} \\
\text { Aorta ant \& left }\end{array}$ & $\begin{array}{l}\mathbf{R} \\
\mathbf{R} \\
\text { Aorta ant \& left }\end{array}$ & $\begin{array}{l}\mathrm{R} \\
\mathrm{R} \\
\text { Aorta ant \& left }\end{array}$ & $\begin{array}{l}\mathbf{R} \\
\mathbf{R} \\
\text { Aorta ant }\end{array}$ \\
\hline Primum (DIRV) & Septal strand & Primum (DILV) & Septal strand & Common atrium \\
\hline $\begin{array}{l}\text { Nil } \\
\text { Common valve } \\
\text { Nil } \\
\text { DIRV } \\
\text { LH } \\
\text { DORV } \\
\end{array}$ & $\begin{array}{l}\text { Yes } \\
\text { Common valve } \\
\text { Yes } \\
\text { Ambiguous } \\
\text { LH } \\
\text { DORV } \\
\text { Subpulm stenosis }\end{array}$ & $\begin{array}{l}\text { Nil } \\
\text { Common valve } \\
\text { Yes } \\
\text { DILV } \\
\text { LH } \\
\text { Discordant } \\
\text { Severe subpulm }\end{array}$ & $\begin{array}{l}\text { Nil } \\
\text { Common valve } \\
\text { Yes } \\
\text { DILV } \\
\text { LH } \\
\text { Single outlet Ao } \\
\text { from RV } \\
\text { PA }\end{array}$ & $\begin{array}{l}\text { Nil } \\
\text { Common valve } \\
\text { Yes } \\
\text { DILV } \\
\text { LH } \\
\text { Single outlet Ao } \\
\text { from RV } \\
\text { PA }\end{array}$ \\
\hline Subpulm stenosis & Subpulm stenosis & $\begin{array}{l}\text { Severe subpulm } \\
\text { stenosis }\end{array}$ & & \\
\hline $\begin{array}{l}\text { Patent } \\
\text { Nil } \\
\text { R-sided patent }\end{array}$ & $\begin{array}{l}\text { Patent } \\
\text { Nil } \\
\text { R-sided patent }\end{array}$ & $\begin{array}{l}\text { Patent } \\
\text { Nil } \\
\text { Patent }\end{array}$ & $\begin{array}{l}\text { Patent } \\
\text { Nil } \\
\text { Patent }\end{array}$ & $\begin{array}{l}\text { Patent } \\
\text { Nil } \\
\text { R-sided patent }\end{array}$ \\
\hline $\begin{array}{l}\text { R } \\
\text { Slit-like } \\
\text { Nil }\end{array}$ & $\begin{array}{l}\text { R } \\
\text { Normal } \\
\text { Nil }\end{array}$ & $\begin{array}{l}\text { R } \\
\text { Normal } \\
\text { RV hypo }\end{array}$ & $\begin{array}{l}\text { L } \\
\text { Normal } \\
\text { RV hypo }\end{array}$ & $\begin{array}{l}\text { R } \\
\text { Normal } \\
\text { RV hypo }\end{array}$ \\
\hline
\end{tabular}


1 Van Mierop LHS, Gessner IH, Schiebler GL. Asplenia and polysplenia syndromes. Birth Defects 1972;VIII (no 5):

Peoples WM, Moller JH, Edwards JE. Polysplenia: a review of 146 cases. Pediatr Cardiol 1983;4:129-37.

3 Macartney FJ, Zuberbuhler JR, Anderson RH. Mor phological considerations pertaining to recognition of atrial isomerism. Consequences for sequential chamber localisation. Br Heart J 1980;44:657-67.

4 Van Praagh R, Van Praagh S, Vlad P, Keith JD. Anatomic types of congenital dextrocardia. Diagnostic and embryologic implications. Am J Cardiol 1964;13:510-31.

5 Anderson RH, Sharma S, Ho SY, Zuberbuhler JR, Macartney FJ. Splenic syndromes, "situs ambiguus" and atrial isomerism. Rev Latina de Card Inf 1986;2:97-110.

6 Sharma S, Devine W, Anderson RH, Zuberbuhler JR. The determination of atrial arrangement by examination of appendage morphology in 1842 heart specimens. Br Heart appendage morph

7 Van Mierop LHS, Wiglesworth FW. Isomerism of the cardiac atria in the asplenia syndrome. Lab Invest cardiac atria in

8 Sharma S, Devine W, Anderson RH, Zuberbuhler JR.
Identification and analysis of left atrial isomerism. $A m \mathrm{~J}$ Cardiol 1987;60:1157-60.

9 Chandra RS. Biliary atresia and other structural anomalies in congenital polysplenia syndrome. J Pediatr 1974;85 649-55.

10 Van Praagh $R$. The segmental approach to diagnosis in congenital heart disease. Birth Defects 1972;VIII (no 5): 4-23.

11 Anderson RH, Becker AE, Freedom RM, et al. Sequential egmental analysis of congenital heart disease. Paediat Cardiol 1984;5:281-8.

12 Van Praagh R, David I, Van Praagh S. What is a ventricle? The single ventricle trap. Pediatr Cardiol 1982;2:79-84.

13 Brandt PWT, Calder AL. Ca tal approach to radiologic diagnosis in congenital heart disease. Curr Probl Diagn Radiol 1977;7:1-35.

14 Deanfield JE, Leanage R, Stroobant J, Chrispin AR, Taylo JFN, Macartney FJ. Use of high kilovoltage filtered beam radiographs for detection of bronchial situs in infants and young children. Br Heart $J$ 1980;44:577-83.

15 Devine WA, Debich DE, Taylor SR. Symmetrical bronchia pattern with normal atrial morphology. Int $J$ Cardiol 1988;20:395-8. 